\title{
Orzeczenie o potrzebie kształcenia specjalnego jako podstawowy dokument organizowania warunków kształcenia specjalnego
}

\begin{abstract}
Mariusz Wielebski, Orzeczenie o potrzebie ksztatcenia specjalnego jako podstawowy dokument organizowania warunków kształcenia specjalnego [Decision on the need for special education as a basic document for organizing special education conditions]. Interdyscyplinarne Konteksty Pedagogiki Specjalnej, nr 20, Poznań 2018. Pp. 161-178. Adam Mickiewicz University Press. ISSN 2300-391X. DOI: 10.14746/ikps. 2018.20.08

Parents who have children with intellectual disability have many difficulties in getting help for their children. First step is collecting documents, second is delivering to Poradnia Psychologiczno-Pedagogiczna, third waiting for the decision, fourth giving it to school and finally getting help. I try to help them and other people. I show, how is important cooperation between parents-teachers-specialist. If it is well we haven't any problems and everything is easy and short.
\end{abstract}

KEY WORDS: ruling, disability, special educational needs, special education

\section{Wprowadzenie}

W polskim systemie oświatowym kształcenie specjalne może odbywać się aktualnie nie tylko w szkołach (przedszkolach, placówkach) specjalnych, ale także integracyjnych i w ramach eduka- 
cji włączającej¹. Ze względu na różne możliwości tych placówek (w tym przygotowanie nauczycieli do wspierania ucznia ze specjalnymi potrzebami edukacyjnymi), wyjątkowe wyzwanie stoi przed publicznymi poradniami psychologiczno-pedagogicznymi wydającymi orzeczenie o potrzebie kształcenia specjalnego - podstawowy dokument, który umożliwia zorganizowanie warunków kształcenia specjalnego $\mathrm{w}$ wybranej dla ucznia szkole. W niniejszym artykule chciałbym przekazać kilka refleksji dotyczących tworzenia i funkcjonowania tego dokumentu z punktu widzenia konfrontacji założeń teorii kształcenia specjalnego, aktualnych ram prawnych oraz praktyki poradniczej. Do poradni psychologiczno-pedagogicznej zgłaszają się rodzice lub prawni opiekunowie dziecka z prośbą "o wydanie orzeczenia”. Niekiedy nie wiedzą, czego ma ono dotyczyć. Trudno im się dziwić, gdyż system wsparcia dziecka z niepełnosprawnością i jego rodziny w Polsce jest dość złożony². Rodzice nie wiedzą, że publiczne poradnie psychologiczno-pedagogiczne wydają orzeczenia $\mathrm{w}$ różnych sprawach, których lista jest dokładnie określona prawem oświatowym ${ }^{3}$.

${ }^{1}$ I. Chrzanowska Pedagogika specjalna. Od tradycji do wspótczesności, Oficyna Wydawnicza „Impuls”, Kraków 2015; G. Szumski Integracyjne ksztatcenie niepetnosprawnych, Wydawnictwo APS i PWN, Warszawa 2013.

${ }^{2}$ G. Mikołajczyk-Lerman, Między wykluczeniem a integracja - realizacja praw dziecka niepetno-sprawnego i jego rodziny. Analiza socjologiczna, Wydawnictwo UŁ, Łódź 2013; Badanie potrzeb $i$ satysfakcji $z$ wybranych ustug skierowanych do rodzin $z$ dziećmi z orzeczona niepetnosprawnościa w wieku 8-16 lat, red. J. Pyżalski, D. Podgórska-Jachnik, Regionalne Centrum Polityki Społecznej w Łodzi, Łódź 2016; D. Podgórska-Jachnik Praca socjalna z osobami z niepetnosprawnościa $i$ ich rodzinami, Centrum Rozwoju Zasobów Ludzkich MPiPS, Warszawa 2014.

${ }^{3}$ Rozporządzenie Ministra Edukacji Narodowej z 7 września 2017 r. w sprawie orzeczeń i opinii wydawanych przez zespoły orzekające działające w publicznych poradniach psychologiczno-pedagogicznych (Dz. U. 2017, poz. 1743) 


\section{Orzeczenie o potrzebie kształcenia specjalnego jako podstawa działań dostosowawczych i rewalidacyjnych szkoły}

Na podstawie Rozporządzenia Ministra Edukacji Narodowej z 7 września 2017 r. w sprawie orzeczeń i opinii wydawanych przez zespoły orzekające działające $\mathrm{w}$ publicznych poradniach psychologiczno-pedagogicznych (Dz. U. z 2017 r., poz. 1743) publiczne poradnie psychologiczno-pedagogiczne wydają orzeczenia o potrzebie kształcenia specjalnego. Należy nadmienić, że takie orzeczenia mogą wydawać tylko poradnie publiczne4. Orzeczenie o potrzebie kształcenia specjalnego może być wydane ze względu na niepełnosprawność ucznia, jego niedostosowanie społeczne lub zagrożenie niedostosowaniem społecznym. Rozporządzenie ministerialne zawiera zamknięty katalog niepełnosprawności, które mogą być wzięte pod uwage $w$ celu wydania orzeczenia o potrzebie kształcenia specjalnego, precyzuje kto jest dzieckiem/uczniem niepełnosprawnym i określa warunki ich kształcenia i wychowania5. Czytamy w dokumencie:

§ 13 pkt.2 W orzeczeniu o potrzebie kształcenia specjalnego zespół określa:

1) diagnozę funkcjonowania dziecka lub ucznia, z uwzględnieniem potencjału rozwojowego oraz mocnych stron i uzdolnień dziecka lub ucznia oraz występujących w środowisku nauczania i wychowania barier i ograniczeń utrudniających jego funkcjonowanie;

2) okres, w jakim zachodzi potrzeba kształcenia specjalnego;

3) zalecane warunki i formy wsparcia umożliwiające realizację indywidualnych potrzeb rozwojowych i edukacyjnych dziecka lub ucznia, w tym warunki rozwijania jego potencjalnych możliwości i mocnych

${ }^{4} \mathrm{~W}$ przypadku otrzymania takiego orzeczenia z poradni niepublicznej należy natychmiast powiadomić Kuratora Oświaty o złamaniu prawa.

${ }^{5}$ Rozporządzenie Ministra Edukacji Narodowej z 9 sierpnia 2017 r. w sprawie warunków organizowania kształcenia, wychowania i opieki dla dzieci i młodzieży niepełnosprawnych, niedostosowanych społecznie i zagrożonych niedostosowaniem społecznym (Dz. U. z 24 sierpnia 2017 r., poz. 1578). 
stron, wzmacniania aktywności i uczestnictwa dziecka lub ucznia w życiu przedszkola, szkoły, ośrodka lub placówki, oraz jeżeli zachodzi potrzeba indywidualnego wsparcia dziecka lub ucznia ze strony dodatkowo zatrudnionej kadry, o której mowa w przepisach w sprawie warunków organizowania kształcenia, wychowania i opieki dla dzieci i młodzieży niepełnosprawnych, niedostosowanych społecznie i zagrożonych niedostosowaniem społecznym - zakres tego wsparcia;

4) zalecane cele rozwojowe i terapeutyczne do realizacji podczas zajęć wychowania przedszkolnego lub zajęć edukacyjnych, zajęć rewalidacyjnych, socjoterapeutycznych i resocjalizacyjnych oraz $\mathrm{w}$ ramach pomocy psychologiczno-pedagogicznej udzielanej dziecku lub uczniowi i, w zależności od potrzeb, jego rodzicom, przez przedszkole, szkołę, ośrodek lub placówkę oraz poradnię, wraz ze wskazaniem zalecanych form pomocy psychologiczno-pedagogicznej, a w przypadku dzieci i uczniów niepełnosprawnych - również zalecanych rodzajów zajęć rewalidacyjnych;

5) wszystkie możliwe formy kształcenia specjalnego, poczynając od najkorzystniejszej dla dziecka lub ucznia, według zespołu, formy kształcenia specjalnego spośród następujących:

a) w przedszkolu (oddziale) ogólnodostępnym, integracyjnym, specjalnym, innej formie wychowania przedszkolnego - w przypad$\mathrm{ku}$ dzieci niepełnosprawnych,

b) w szkole (oddziale) ogólnodostępnej, integracyjnej lub specjalnej - w przypadku uczniów niepełnosprawnych, niedostosowanych społecznie lub zagrożonych niedostosowaniem społecznym,

c) w szkole specjalnej w młodzieżowym ośrodku wychowawczym w przypadku nieletnich, wobec których sąd rodzinny orzekł o umieszczeniu w tym ośrodku,

d) w szkole specjalnej w młodzieżowym ośrodku socjoterapii w przypadku uczniów zagrożonych niedostosowaniem społecznym,

e) w przedszkolu specjalnym albo szkole specjalnej w specjalnym ośrodku szkolno-wychowawczym - w przypadku dzieci lub uczniów, którzy z powodu niepełnosprawności nie mogą uczęszczać do przedszkola lub szkoły w miejscu zamieszkania,

f) w specjalnym ośrodku wychowawczym - w przypadku uczniów: - niepełnosprawnych, którzy z powodu niepełnosprawności nie mogą uczęszczać do szkoły w miejscu zamieszkania, specjalne- 
go ośrodka szkolno-wychowawczego lub nie mogą przebywać w bursie,

- zagrożonych niedostosowaniem społecznym,

g) w ośrodku rewalidacyjno-wychowawczym - w przypadku dzieci

lub uczniów z niepełnosprawnościami sprzężonymi, z których jedną z niepełnosprawności jest niepełnosprawność intelektualna;

6) potrzebę realizacji wybranych zajęć wychowania przedszkolnego lub zajęć edukacyjnych indywidualnie $\mathrm{z}$ dzieckiem lub uczniem lub $\mathrm{w}$ grupie liczącej do 5 dzieci lub uczniów - w przypadku dziecka lub ucznia napotykającego na trudności w funkcjonowaniu wspólnie z oddziałem przedszkolnym lub szkolnym;

7) zalecane działania ukierunkowane na poprawę funkcjonowania dziecka lub ucznia i wzmacnianie jego uczestnictwa w życiu przedszkola, szkoły, ośrodka lub placówki oraz działania wspierające rodziców dziecka lub ucznia;

8) w zależności od potrzeb dziecka lub ucznia niepełnosprawnego, niezbędny w procesie kształcenia sprzęt specjalistyczny i środki dydaktyczne, w tym $\mathrm{z}$ wykorzystaniem technologii informacyjnokomunikacyjnych;

9) zalecane sposoby oceny efektów działań podjętych przez przedszkole, szkołę, ośrodek lub placówkę w celu realizacji zaleceń, o których mowa w pkt 3-86.

Informacje zawarte $\mathrm{w}$ jego poszczególnych modułach są niezwykle ważne dla napisania dobrego Indywidualnego Programu Edukacyjno-Terapeutycznego (IPET), a więc i pracy szkoły, w której kształcić będzie się uczeń. Ponieważ w orzeczeniu określony jest czas, w którym ono obowiązuje (najczęściej jest to etap edukacyjny) Indywidualny Program Edukacyjno-Terapeutyczny piszemy na taki sam okres, jaki został wskazany w orzeczeniu. Warto pamiętać o tym, że w określonych warunkach dany etap edukacyjny może trwać dłużej niż liczba lat nauki jemu przypisanych. Uczniowi z niepełnosprawnością intelektualną w stopniu lekkim można wydłużyć czas nauki o trzy lata, czyli do 21. roku życia, zaś z niepełno-

${ }^{6}$ Rozporządzenie Ministra Edukacji Narodowej z 7 września 2017 r. w sprawie orzeczeń i opinii..., op. cit. 
sprawnością intelektualną w stopniu umiarkowanym i znacznym do 24. roku życia, czyli nawet o pięć lat. Odpowiednio więc można wydłużać uczniowi etapy edukacyjne w zależności od jego rozwoju intelektualnego i postępów edukacyjnych7.

Pierwszą częścią merytoryczną orzeczenia o potrzebie kształcenia specjalnego jest diagnoza. „Zespół Orzekający przedstawia diagnozę funkcjonowania dziecka lub ucznia, z uwzględnieniem potencjału rozwojowego oraz mocnych stron i uzdolnień dziecka"8. $\mathrm{Na}$ podstawie wyników badań psychologiczno-pedagogicznych oraz dokumentacji medycznej (posiadanych kserokopii orzeczeń lekarskich, kart informacyjnych dotyczących pobytu w szpitalu, opisu innych specjalistycznych badań dostarczonych przez wnioskodawcę, czyli rodzica lub prawnego opiekuna dziecka) oraz diagnozy funkcjonalnej, wykonanej przez nauczycieli, powstaje diagnoza - pierwsza część orzeczenia. Jest ona o tyle ważna, że na podstawie diagnozy pisane są zalecenia i ich uzasadnienie, czyli kolejne części dokumentu. Sprzeczność pomiędzy treścią zgromadzonych dokumentów i wydanego przez poradnię orzeczenia, może być podstawą do odwołania się rodzica od jego treści ${ }^{9}$.

W codziennej pracy poradni psychologiczno-pedagogicznych spotykamy bardzo różne postawy rodziców/prawnych opiekunów - wnioskodawców, od których rozpoczyna się cała procedura diagnostyczno-orzecznicza. Warto nadmienić, że brak formalnej zgody rodziców na badanie dziecka (jest to istotny wymóg formalny) może stanowić o wadzie prawnej samego dokumentu, powodującej jego nieważność. Część z rodziców składa tylko sam wniosek. Dopiero po przybyciu do poradni okazuje się, że dziecko najpierw należy przebadać. $W$ tym momencie może pojawić się kolejny problem, wynikający z czasu oczekiwania na wydanie orzeczenia, któ-

${ }_{7}$ M. Grzesiak, Kogo dotyczy wydtużanie cyklu edukacyjnego, Poradnia Psychologiczno-Pedagogiczna w Lubaniu, http://www.pppluban.org/www/porada_dnia /ppp_porada_dnia_wydluzenie_etapu_edukacyjnego.pdf, [dostęp: 15.03.2017].

${ }^{8}$ Rozporządzenie Ministra Edukacji Narodowej z 7 września 2017 r. w sprawie orzeczeń i opinii..., op. cit.

${ }^{9}$ A. Dudzińska, A. Niedźwiedzka, op. cit., s. 11-13. 
ry może trwać nawet kilka miesięcy. Dzieje się tak, gdy zachodzi konieczność wykonania dodatkowych, specjalistycznych badań lekarskich. W takim przypadku poradnia może zaproponować rodzicowi/prawnemu opiekunowi czasowe wystawienie jedynie opinii o dziecku lub, na podstawie posiadanych badań, wydać orzeczenie na jeden rok szkolny, a w zaleceniach umieścić informację o konieczności dalszej diagnostyki u konkretnego specjalisty. Czasami jednak problemem staje się wyegzekwowanie od rodzica/prawnego opiekuna dziecka jakichkolwiek dokumentów poza wnioskiem o wydanie orzeczenia. Wtedy przewodniczący zespołu orzekającego może wystąpić do dyrektora odpowiedniej szkoły/placówki edukacyjnej o napisanie opinii, której elementy określa rozporządzenie w sprawie orzeczeń. Szkoła ma siedem dni na napisanie ww. opinii ${ }^{10}$.

Niekiedy można spotkać rodziców, których głównym celem jest jedynie uzyskanie orzeczenia, bowiem na jego podstawie chcą ubiegać się o dodatkowe środki finansowe w postaci zasiłku czy inne formy wsparcia socjalnego. Niestety, jak wspomniano we wstępie, bywa, że rodzice nie odróżniają orzeczenia o potrzebie kształcenia specjalnego (lub innych orzeczeń poradnianych) od orzeczenia o niepełnosprawności dziecka, nie znają wynikających z nich (różnych) uprawnieńn ${ }^{11}$. Zdarza się bardzo często, że są to osoby roszczeniowe, zgadzają się one na diagnozę dziecka lub przynoszą dokumenty diagnostyczne $\mathrm{z}$ niepublicznych poradni, a nawet z prywatnych gabinetów. Tylko możliwość uzyskania przez nich orzeczenia o braku potrzeby kształcenia specjalnego ich dzieci pozwala na prawidłowe zdiagnozowanie dziecka. Tacy rodzice mają świadomość, że w przypadku niezdiagnozowania ich dziecka i w efekcie otrzymanie orzeczenia o braku potrzeby kształcenia spe-

$10 \S 7$ ust. 3 Rozporządzenie Ministra Edukacji Narodowej z 7 września 2017 r. w sprawie orzeczeń i opinii..., op. cit.

${ }^{11}$ Niestety, w praktyce okazuje się, że nie tylko rodzice, ale również szkoły szczególnie ogólnodostępne, o ograniczonym doświadczeniu w pracy z uczniem z niepełnosprawnością - mają problemy z różnicowaniem tych orzeczeń i wynikających z nich uprawnień. 
cjalnego nie będą mogli ubiegać się o jakiekolwiek wsparcie (finansowe, np. dodatkowe zajęcia rewalidacyjne). W skrajnym przypadku szkoła może skierować do sądu rodzinnego informację o źle wykonywanej władzy rodzicielskiej. Na szczęście z perspektywy doświadczeń poradni wynika, że z roku na rok takich rodziców jest coraz mniej.

Po zakończeniu badań diagnostycznych, koordynowanych przez poradnię, ich wyniki opisywane są $\mathrm{w}$ pierwszej części orzeczenia. W jaki sposób skorzystać z nich przy pisaniu Indywidualnego Programu Edukacyjno-Terapeutycznego? Z dokumentu można uzyskać wiedzę: 1) o podstawie programowej, która będzie odpowiednia dla ucznia, 2) o chorobach somatycznych dziecka, 3) o liczbie i rodzaju specjalistów, z którymi uczeń powinien mieć zajęcia, 4) na temat tego, jak funkcjonuje ono $w$ grupie, jak rozwinięte są jego możliwości psychiczne i fizyczne, jak funkcjonuje w stosunku do swojego wieku metrykalnego, jaki posiada potencjał (możliwości i mocne strony dziecka).

Drugą częścią orzeczenia o potrzebie kształcenia specjalnego są zalecenia. Zgodnie ze wzorem znajdującym się z rozporządzeniu w bardzo szczegółowy sposób określają one, w jaki sposób należy prowadzić wsparcie dla danego ucznia ${ }^{12}$. Obowiązkowym zapisem w tej części dokumentu są zajęcia rewalidacyjne, czyli złożone działania o

charakterze leczniczym, psychologicznym, pedagogicznym i społeczno-zawodowym, które zmierzają do rozwinięcia lub przywrócenia u osoby trwale poszkodowanej na zdrowiu sprawności, zdolności i możliwości niezbędnych do jej prawidłowego funkcjonowania ${ }^{13}$ lub też - inaczej ujmując: przywrócenie - w możliwie wysokim stopniu sprawności organizmu oraz poczucia własnej wartości społecznej, zawodowej i rodzinnej ${ }^{14}$.

12 Rozporządzenia Ministra Edukacji Narodowej z 7 września 2017 r. w sprawie orzeczeń i opinii..., op. cit.

13 A. Maciarz Wybrane zagadnienia rewalidacji dzieci, Wydawnictwo WSP, Zielona Góra 1984, s. 18.

14 Encyklopedia Powszechna PWN (1085), Warszawa, wyd. III, tom 3, s. 861. 
Termin rewalidacja pokrewny jest terminowi rehabilitacja, przy czym rewalidacja odnosi się zwykle do wychowania i kształcenia dzieci i młodzieży ${ }^{15}$, stąd $\mathrm{w}$ pedagogice specjalnej traktowana jest jako podstawowe oddziaływanie wobec uczniów z niepełnosprawnością. W zależności od rodzaju niepełnosprawności określa się na podstawie specjalistycznej diagnozy odpowiedni dla danego dziecka poziom adaptacji i wynikający z niego zakres zajęć rewalidacyjnych ${ }^{16}$. W szczególności dla uczniów niewidomych zaleca się $w$ ramach rewalidacji naukę orientacji przestrzennej i poruszania się, naukę alfabetu Braille'a lub innych alternatywnych metod komunikacji; dla uczniów z uszkodzonym słuchem lub afazją - naukę języka migowego czy innych wspomagających lub alternatywnych form komunikacji; dla uczniów $\mathrm{z}$ autyzmem, w tym $\mathrm{z}$ zespołem Aspergera - zajęcia rozwijające umiejętności społeczne, w tym umiejętności komunikacyjne ${ }^{17}$. Dlatego należy uznać określanie celów rewalidacji za kluczowy i zarazem jeden z najbardziej zindywidualizowanych elementów diagnozy poradnianej, uwzględniający także szerszy kontekst środowiskowy sytuacji dziecka. Podkreślam to, bo mimo tego, że pojęcie rewalidacji jest wszechobecne w polskim systemie oświaty, odkąd zaczął on realizować założenia edukacji włączającej, to nadal spotyka się ono z ogromnym niezrozumieniem. Trafnie określa problem stanowienia celów rewalidacji Bożena Grochmal-Bach, która pisze:

Przy prowadzeniu procesu rewalidacji należy określić to, co jest wspólne dla wszystkich ludzi pełnosprawnych i niepełnosprawnych oraz to, co jest indywidualne i wymaga specyficznego podejścia. Czynnikiem rozstrzygającym jest zakres i stopień zakłócenia równowagi między jednostką a środowiskiem, a nie rodzaj upośledzonej funkcji organizmu ${ }^{18}$.

15 B. Grochmal-Bach Wychowanie $i$ terapia w rewalidacji dzieci i młodzieży, Oficyna Wydawnicza „Impuls”, Kraków 2001, s. 10-11.

16 Ibidem, s. 67.

17 Rozporządzenie Ministra Edukacji Narodowej z 24 lipca 2015 r. w sprawie warunków organizowania kształcenia..., op. cit.

18 B. Grochmal-Bach, op. cit., s. 9. 
Uczeń posiadający orzeczenie o potrzebie kształcenia specjalnego realizuje dodatkowe i obowiązkowe dwie godziny rewalidacji. Ich liczbę oraz sposób realizacji określa rozporządzenie Ministra Edukacji Narodowej z 7 lutego 2012 r. w sprawie ramowych planów nauczania w szkołach publicznych ${ }^{19}$.

Kolejnym obowiązkowym zapisem w zaleceniach jest określenie zakresu pomocy psychologiczno-pedagogicznej dla danego dziecka. Zadaniem zespołu orzekającego poradni psychologiczno-pedagogicznej jest wskazanie wszystkich potrzebnych zajęć specjalistycznych, które mają na celu pomoc dziecku. Warto zauważyć, że zajęcia te określa się nie dla konkretnej szkoły, ale dla konkretnego dziecka. W Rozporządzeniu Ministra Edukacji Narodowej z 9 sierpnia 2017 r. w sprawie zasad udzielania i organizacji pomocy psychologiczno-pedagogicznej w publicznych przedszkolach, szkołach i placówkach znajduje się wykaz form pomocy psychologiczno-pedagogicznej, określone są procedury tworzenia klas terapeutycznych, wskazane są rodzaje zajęć, w których może uczestniczyć uczeń oraz dopuszczalna maksymalną liczba ich uczestników ${ }^{20}$.

Zdarza się, że szkoły mają do poradni pretensje, że wpisują $\mathrm{w}$ zalecenie zajęcia, których $\mathrm{w}$ szkole nie ma lub nie ma do nich zatrudnionego specjalisty. Jak wspomniałem, orzeczenie nie jest pisane dla szkoły, a tym bardziej dla konkretnej szkoły. Jest niezależnym dokumentem, do którego należy dostosować określone warunki edukacji, a nie odwrotnie. Wnioskodawca - rodzic lub prawny opiekun - może na piśmie wystąpić do dyrektora szkoły z prośbą o zorganizowanie dodatkowych zajęć. Dyrektorzy szkół ogólnodostępnych zobowiązani są organizować zajęcia prowadzone, np. przez pedagoga szkolnego. Nie zawsze - szczególnie w edukacji włączającej, gdy szkoła nie zetknęła się dotąd z potrze-

19 Rozporządzenia Ministra Edukacji Narodowej z 28 marca 2017 w sprawie ramowych planów nauczania w szkołach publicznych (Dz. U. 2017 z 31 marca 2017 r., poz. 1578).

${ }^{20}$ Rozporządzenia Ministra Edukacji Narodowej z 9 sierpnia 2017 r w sprawie w sprawie zasad udzielania i organizacji pomocy psychologiczno-pedagogicznej ..., op. cit. 
bami wynikającymi z niepełnosprawności intelektualnej ucznia znane są dyrekcji szkół wszystkie zasady współpracy z samorządem powiatowym lub gminnym $w$ tym zakresie ${ }^{21}$. Warto zauważyć, że $\mathrm{w}$ występowaniu do organu prowadzącego szkołę lub placówkę o dofinansowanie edukacji uczniów z niepełnosprawnością kluczowa będzie treść orzeczeń o potrzebie kształcenia specjalnego znajdujących się w dyspozycji szkoły. Dlatego należy umieć je dobrze odczytywać (z jednej strony - jakie zajęcia rewalidacyjne i specjalistyczne należy zorganizować dla uczniów, ilu i jakich nauczycieli czy asystentów zatrudnić - z drugiej, które jednostki diagnostyczne uprawniają do sięgnięcia po dotację celową i jakie przeliczniki można tutaj zastosować22).

Zdarza się również, że np. uczeń niepełnosprawny intelektualnie $\mathrm{w}$ stopniu umiarkowanym lub znacznym $\mathrm{z}$ powodu decyzji rodziców uczęszcza do szkoły ogólnodostępnej, a w zaleceniu poradni na pierwszym miejscu ma wpisaną szkołę specjalną. Jest to wybór rodzica lub prawnego opiekuna, wraz ze wszystkimi jego konsekwencjami. Kierują się oni z jednej strony oceną własną jakości kształcenia, z drugiej - perspektywą integracji. Warto zauważyć, że mimo tendencji inkluzyjnych szkoła specjalna może być czasem lepszym wyborem dla ucznia: zapewnia wielu specjalistów, podczas gdy szkoła ogólnodostępna może mieć ich tylko pod warun-

${ }^{21}$ Szkoła powinna wystąpić o odpowiednie środki z dotacji oświatowej do organu prowadzącego, gdyż to na samorządach lokalnych spoczywa - zgodnie z art. 90 Ustawy z dnia 7 września o systemie oświaty (Dz. U. z 2004 r. Nr 256, poz. 2572 z późn. zmianami) - obowiązek zabezpieczenia warunków finansowych do realizacji zaleceń wynikających $\mathrm{z}$ orzeczeń. Aby uzyskać dotację, placówka oświatowa (szkoła) musi zgłosić liczbę uczniów objętych dofinansowaniem do 30 września roku poprzedzającego wypłatę, choć korekty możliwe są także później, z czego nie wszyscy dyrektorzy zdają sobie sprawę (szczegółowe porady: A. Dudzińska, A. Niedźwiedzka, op. cit.).

${ }^{22}$ Zob. np. dyskusję i (zmieniające się) stanowisko MEN: Dzieci z całościowymi zaburzeniami rozwoju nie mają prawa do orzeczenia o potrzebie kształcenia specjalnego, Portal Internetowy Stowarzyszenia Wszystko Jasne, 24 sierpnia 2014, [online] http://www.wszystkojasne.waw.pl/dzieci-calosciowymi-zaburzeniami-roz woju-nie-maja-prawa-orzeczenia-potrzebie-ksztalcenia-specjalnego/ [dostęp: 8.05.2017]. 
kiem posiadania środków finansowych na ich zatrudnienie. Decyduje o tym zawsze indywidulanie organ prowadzący. Czasem jedyną formą realizacji zaleceń poradni są dwie godziny zajęć rewalidacyjnych, na które są wydzielone fundusze dla każdego ucznia posiadającego orzeczenie o potrzebie kształcenia specjalnego - bez znaczenia w jakiej jest szkole. Niezależnie od tego, czy szkoła posiada środki finansowe, czy nie - jej zadaniem jest organizacja jak najlepszej pomocy dziecku. $\mathrm{W}$ tym zakresie szkoła może zaproponować część zajęć - np. terapię pedagogiczną lub/i logopedyczną - w poradni psychologiczno-pedagogicznej lub poszukać innych instytucji czy miejsc, np. świetlic osiedlowych, centrów pomocy społecznej, czasami lokalnych organizacji pozarządowych ${ }^{23}$ realizujących projekty własne lub zadania zlecone przez samorząd, gdzie taką pomoc ich uczniowie będą mogli otrzymać. Dużo zależy od przedsiębiorczości i kreatywności dyrektora placówki, czasem samych rodziców.

Każde zalecenie wymaga uzasadnienia, w którym należy wskazać elementy diagnozy argumentujące potrzebę kształcenia specjalnego i zalecane, najkorzystniejsze dla ucznia formy pomocy psychologiczno-pedagogicznej oraz określić jej spodziewane efekty. $\mathrm{W}$ przypadku wydania nowego orzeczenia o potrzebie kształcenia specjalnego należy wskazać okoliczności, które Zespół Orzekający Poradni uznał za istotne dla ponownego rozstrzygnięcia oraz wyjaśnić powody wydania nowego orzeczenia ${ }^{24}$. W tej części należy uzasadnić potrzebę objęcia ucznia kształceniem specjalnym oraz wyjaśnić motywację wyboru przez Zespół takich, a nie innych form pomocy psychologiczno-pedagogicznej. W przypadku uczniów niepełnosprawnych intelektualnie konieczne jest uzasadnienie wyboru określonego typu szkoły. O tym, że wybory te mogą być różne, decyduje podstawa programowa. Ponieważ jest ona taka sama

${ }^{23}$ I. Chrzanowska Strategia kształcenia osób niepetnosprawnych. Diagnoza pozoru [w:] Człowiek z niepetnosprawnością w rezerwacie przestrzeni publicznej, red. Z. Gajdzica, Oficyna Wydawnicza „Impuls”, Kraków 2013, s. 194-195.

${ }^{24}$ Rozporządzenia Ministra Edukacji Narodowej z 18 września 2008 roku w sprawie orzeczeń i opinii..., op. cit. 
dla uczniów w normie intelektualnej i niepełnosprawnych intelektualnie w stopniu lekkim - tych drugich należy kierować do szkół ogólnodostępnych, integracyjnych lub z oddziałami integracyjnymi. Podstawa programowa jest inna dla osób niepełnosprawnych intelektualnie w stopniu umiarkowanym i znacznym ${ }^{25}$, którzy powinni zostać skierowani do szkół specjalnych. Uzasadniamy również dlaczego została wybrana np. terapia pedagogiczna i w jaki sposób może przyczynić się ona do właściwego rozwoju i funkcjonowania naszego podopiecznego. Dlatego właśnie pierwsza część orzeczenia - diagnoza - ma tak ogromne znaczenie, wpływa ona bowiem na dalsze jego części.

Aktualnie coraz częściej zdarza się, że rodzice dzieci niepełnosprawnych intelektualnie $\mathrm{w}$ stopniu umiarkowanym postanawiają o pozostawieniu ich w szkole ogólnodostępnej. Wiadomość o niepełnosprawności intelektualnej dziecka dla jego rodzica jest bardzo przykrą i trudną do przyjęcia wiadomością, stąd wybór szkoły specjalnej staje się dla niego często nie do zaakceptowania. A szkoda, ponieważ szkoła specjalna posiada wykwalifikowanych nauczycieli, mało liczne klasy, odpowiednie podręczniki i pomoce dydaktyczne oraz często umożliwia swoim wychowankom zdobycie kwalifikacji zawodowych. Szkoła ta pomaga również w znalezieniu pracy lub umieszczenia dorosłego już absolwenta w zakładach pracy chronionej lub w warsztatach terapii zajęciowej.

Dlaczego więc rodzic wybiera szkołę ogólnodostępną? Z perspektywy wieloletniego doświadczenia zawodowego pracownika

${ }^{25}$ Warto dodać w tym miejscu, że podstawa programowa dla uczniów z niepełnosprawnością intelektualną $\mathrm{w}$ stopniu umiarkowanym i znacznym została objęte reformą oświatową (2017) i wchodzi aktualnie w życie (zob. Rozporządzenie Ministra Edukacji Narodowej z dnia 14 lutego 2017 r. w sprawie podstawy programowej wychowania przedszkolnego oraz podstawy programowej kształcenia ogólnego dla szkoły podstawowej, w tym dla uczniów z niepełnosprawnością intelektualną w stopniu umiarkowanym lub znacznym, kształcenia ogólnego dla branżowej szkoły I stopnia, kształcenia ogólnego dla szkoły specjalnej przysposabiającej do pracy oraz kształcenia ogólnego dla szkoły policealnej, Dz. U. z 24 lutego 2017 r., poz. 356). 
poradni wynika, że jednym z najczęstszych czynników mających wpływ na podjęcie takiej decyzji jest presja środowiska. Rodzic liczy się z opinią sąsiadów, znajomych, rodziny. Często myśli, że dzięki takiemu wyborowi jego dziecko nie będzie tak bardzo „inne” - będzie przecież chodzić do tej samej szkoły, do której chodzą wszystkie dzieci z osiedla. Ma także nadzieję, że jego dziecko rozwinie się, pozostając w środowisku kolegów z osiedlowego podwórka. Kolejną przyczyną jest często konieczność dowozu dziecka do położonej daleko od miejsca zamieszkania szkoły specjalnej, co wiąże się z nakładem środków finansowych. Bywa, że trzeba rozważyć umieszczenie dziecka w internacie, co znowu może wzmagać opór opiekunów. W tych okolicznościach i przy tak dużej presji środowiska rodzic podejmuje decyzję o pozostawieniu swojego dziecka w szkole ogólnodostępnej, w której jego dziecko będzie pracowało w oparciu o przygotowany dla niego Indywidualny Program Edukacyjno-Terapeutyczny.

Trzeba też dodać, że zapisy ratyfikowanej w 2012 r. przez Prezydenta Polski Konwencji o Prawach Osób Niepełnosprawnych stworzyły pewien rodzaj hierarchii, gdyż zapis o prawie do edukacji włączającej na wszystkich poziomach kształcenia26, odczytywany bywa jako nadanie jej bezwzględnie najwyższej wartości w edukacyjnych wyborach dotyczących osób z niepełnosprawnością. Tymczasem edukacja włączająca, która miała być odpowiedzią systemu oświaty na proces wyłączania, powinna być traktowana jako możliwość wyboru optymalnej formy kształcenia. Oznacza to jej indywidualizację w przypadku różnych uczniów ${ }^{27}$. Decyzja o wyborze szkoły dla ucznia wymaga więc przemyślenia - i przez pracowników poradni psychologiczno-pedagogicznej, i przez rodziców faktycznych potrzeb i motywacji, związanych z tym wyborem, poprzedzonych dyskusją i porozumieniem obu stron, które znajdzie

${ }^{26}$ Konwencja o prawach osób niepełnosprawnych, sporządzona w Nowym Jorku dnia 13 grudnia 2006 r. [online], Art. 24. [online] [dostęp: 2.05.2017] <http://isap.sejm.gov.pl/DetailsServlet?id=WDU20120001169>.

27 D. Podgórska-Jachnik, op. cit., s. 63-66. 
swoje odzwierciedlenie także w zaleceniach orzeczenia o potrzebie kształcenia specjalnego.

Na końcu należy jeszcze wspomnieć, że obecnie Ministerstwo Edukacji Narodowej informuje o trwających pracach nad nowymi rozwiązaniami, mającymi na celu podniesienie jakości wsparcia dla uczniów w procesie kształcenia i wychowania. Dotyczy to podniesienia rzetelności i trafności diagnozy ich potrzeb edukacyjnych i rozwojowych, uwzględniającej jej funkcjonalny model biopsychospołeczny, w tym kontekst funkcjonowania dziecka w środowisku nauczania i wychowania:

Ten model diagnozy oparty jest o analizę nie tylko danych o indywidualnych cechach dziecka, ale również barierach i zasobach $w$ jego środowisku, z uwzględnieniem informacji z różnych źródeł (np. lekarz, szkoła, opieka społeczna) ${ }^{28}$.

W nowym modelu planuje się wykorzystanie Międzynarodowej Klasyfikacji Funkcjonowania, Niepełnosprawności i Zdrowia (ICF International Classificaton of Fuctioning, Disability and Health) - wersji dla dzieci i młodzieży (ICF-CY - International Classificaton of Fuctioning, Disability and Health - Children and Youth) ${ }^{29}$. Wypracowany już w ten sposób model diagnozy uczniów ze Specjalnymi Potrzebami Edukacyjnymi znalazł swoje odzwierciedlenie w nowych wzorach orzeczeń o potrzebie kształcenia specjalnego. Jego pozytywną cechą będzie z pewnością większa obiektywizacja i rzetelność sporządzanych diagnoz, ujednolicenie ich języka, a także sprofilowanie funkcjonalnych aspektów diagnozy pod kątem jej użyteczności w projektowanym wsparciu edukacyjnym. Oznacza to, że szkołom na pewno łatwiej będzie sporządzać IPET-y, trafniej dobierać niezbędne formy pomocy. Aspekt negatywny to na pewno wyzwanie zwią-

28 Reforma edukacji a uczeń ze specjalnymi potrzebami edukacyjnymi, Portal informacyjno-promocyjny „Dobra Szkoła” Ministerstwa Edukacji Narodowej, [online] https://reformaedukacji.men.gov.pl/aktualnosci/reforma-edukacji-a-uczen-zespecjalnymi-potrzebami-edukacyjnymi.html, [dostęp: 29.05.2017].

${ }^{29}$ Ibidem. 
zane ze zmierzeniem się środowiska z nowym warsztatem diagnostyczno-orzeczniczym, konieczność pokonania oporów mentalnych przed nowością i przebudowa sposobu myślenia o zadaniach związanych z orzekaniem o potrzebie kształcenia specjalnego.

\section{Podsumowanie}

Podsumowując niniejsze rozważania, chciałbym wskazać najważniejsze poruszone problemy. Otóż warto zapamiętać, że:

1) ze względu na różne możliwości wyboru ścieżki kształcenia ucznia w systemie oświaty realizującym zasadę inkluzji, przed Zespołem Orzekającym Poradni Psychologiczno-Pedagogicznej, wydającym orzeczenie o potrzebie kształcenia specjalnego, stoi duże wyzwanie. Jakość tego dokumentu jest wstępnym warunkiem optymalnego organizowania warunków kształcenia specjalnego - bez względu na to, jaką szkołę wybiorą dla ucznia jego rodzice;

2) ze względu na rangę i znaczenie orzeczenia o potrzebie kształcenia specjalnego konieczne jest upowszechnianie wiedzy na jego temat, szczególnie wśród rodziców, opiekunów dziecka oraz nauczycieli edukacji włączającej (czyli wśród kadry pedagogicznej szkół ogólnodostępnych);

3) poradnia psychologiczno-pedagogiczna powinna dołożyć wszelkich starań, by poprzez rzetelną diagnozę i trafne zalecenia ułatwić rodzicom optymalny wybór szkoły dla dziecka z niepełnosprawnością, a szkole dostarczyć dobry materiał do tworzenia IPET-u;

4) nauczyciele - szczególne w szkołach ogólnodostępnych, niebędący pedagogami specjalnymi - powinni zdobyć wiedzę i umiejętności $\mathrm{w}$ zakresie rozumienia zapisów zawartych $\mathrm{w}$ orzeczeniach, przede wszystkim $\mathrm{w}$ ich części diagnostycznej. Zamieszczone $\mathrm{w}$ zaleceniach uzasadnienia, np. doboru rodzaju zajęć rewalidacyjnych można traktować jako wskazówkę w przypadku ewentualnych niejasności. Należy pa- 
miętać, że szkoła może w tym względzie liczyć na współpracę i wsparcie poradni czy ośrodków doskonalenia nauczycieli, oraz że warto z tego wsparcia korzystać.

5) system oświaty - zarówno poradnie, jak i szkoły, przedszkola, placówki - powinien przygotować się do nowego modelu diagnozy funkcjonalnej, opartego na kategoriach ICF. Może to być początkowo trudne, ale warto upatrywać w tym szansę polepszenia jakości orzeczeń w przyszłości oraz ułatwienie placówkom pracy nad PET-em dostosowanym do zindywidualizowanych potrzeb rozwojowych i edukacyjnych ucznia/ dziecka z niepełnosprawnością.

\section{Bibliografia}

Badanie potrzeb $i$ satysfakcji $z$ wybranych ustug skierowanych do rodzin $z$ dziećmi $z$ orzeczoną niepetnosprawnością w wieku 8-16 lat, red. J. Pyżalski, D. Podgórska-Jachnik, Regionalne Centrum Polityki Społecznej w Łodzi, Łódź 2016.

Chrzanowska I., Strategia ksztatcenia osób niepetnosprawnych. Diagnoza pozoru [w:] Człowiek z niepetnosprawnością w rezerwacie przestrzeni publicznej, red. Z. Gajdzica, Oficyna Wydawnicza „Impuls”, Kraków 2013.

Chrzanowska I., Pedagogika specjalna. Od tradycji do wspótczesności, Oficyna Wydawnicza „Impuls”, Kraków 2015.

Dudzińska A., Niedźwiedzka A., Najczęstsze pytania dotyczace kształcenia specjalnego informator dla rodziców, [online] http://niegrzecznedzieci.org.pl/wp-content/ uploads/2016/01/WszystkoJasne-Raport-Najcze\%CC\%A8stsze-Pytania-Dotycza\% CC\%A8ce-Kszta\%C5\%82cenia-Specjalnego.pdf [dostęp: 2.05.2017].

Dzieci z całościowymi zaburzeniami rozwoju nie maja prawa do orzeczenia o potrzebie ksztatcenia specjalnego, Portal Internetowy Stowarzyszenia Wszystko Jasne, 24 sierpnia 2014, [online] http://www.wszystkojasne.waw.pl/dzieci-calosciowymi-zaburze niami-rozwoju-nie-maja-prawa-orzeczenia-potrzebie-ksztalcenia-specjalnego

Encyklopedia Powszechna PWN (1985), Warszawa, wyd. III, tom 3.

Grzesiak M., Kogo dotyczy wydłużanie cyklu edukacyjnego, Portal internetowy Poradni Psychologiczno-Pedagogicznej w Lubaniu, [online] http://www.pppluban.org/ www/porada_dnia/ppp_porada_dnia_wydluzenie_etapu_edukacyjnego.pdf [dostęp: 15.03.2017].

Konwencja o prawach osób niepełnosprawnych, sporządzona w Nowym Jorku dnia 13 grudnia 2006 r. [online], http://isap.sejm.gov.pl/DetailsServlet?id=WDU20 120001169 [dostęp: 2.05.2017]. 
Maciarz A., Wybrane zagadnienia rewalidacji dzieci, Wydawnictwo Wyższej Szkoły Pedagogicznej, Zielona Góra 1984.

Grochmal-Bach B., Wychowanie i terapia w rewalidacji dzieci i młodzieży, Oficyna Wydawnicza „Impuls”, Kraków 2001.

Mikołajczyk-Lerman G., Między wykluczeniem a integracja - realizacja praw dziecka niepetno-sprawnego i jego rodziny. Analiza socjologiczna, Wydawnictwo Uniwersytetu Łódzkiego, Łódź 2013.

Szumski G., Integracyjne kształcenie niepetnosprawnych. Wyd. APS i PWN, Warszawa 2013

Podgórska-Jachnik D. Praca socjalna z osobami z niepetnosprawnością i ich rodzinami, Centrum Rozwoju Zasobów Ludzkich MPiPS, Warszawa 2014.

Reforma edukacji a uczeń ze specjalnymi potrzebami edukacyjnymi, Portal informacyjno-promocyjny „Dobra Szkoła” Ministerstwa Edukacji Narodowej, [online] https://reformaedukacji.men.gov.pl/aktualnosci/reforma-edukacji-a-uczenze-specjalnymi-potrzebami-edukacyjnymi.html [dostęp: 29.05.2017]

Wykaz aktów prawnych

Rozporządzenie Ministra Edukacji Narodowej z dnia 18 września 2008 r. w sprawie orzeczeń i opinii wydawanych przez zespoły orzekające działające w publicznych poradniach psychologiczno-pedagogicznych z późn. zm. (Dz. U. 2008, nr 173 poz. 1072).

Rozporządzenia Ministra Edukacji Narodowej z dnia 7 lutego 2012 w sprawie ramowych planów nauczania w szkołach publicznych (Dz. U. 2012, poz. 204).

Rozporządzenia Ministra Edukacji Narodowej z dnia 30 kwietnia 2013 w sprawie w sprawie zasad udzielania i organizacji pomocy psychologiczno-pedagogicznej w publicznych przedszkolach, szkołach i placówkach (Dz. U. 2013, poz. 532).

Rozporządzenie Ministra Edukacji Narodowej z dnia 24 lipca 2015 r. w sprawie warunków organizowania kształcenia, wychowania i opieki dla dzieci i młodzieży niepełnosprawnych, niedostosowanych społecznie i zagrożonych niedostosowaniem społecznym (Dz.U. z dnia 7 sierpnia 2015 r., poz. 1113).

Rozporządzenie Ministra Edukacji Narodowej z dnia 14 lutego 2017 r. w sprawie podstawy programowej wychowania przedszkolnego oraz podstawy programowej kształcenia ogólnego dla szkoły podstawowej, w tym dla uczniów $\mathrm{z}$ niepełnosprawnością intelektualną $\mathrm{w}$ stopniu umiarkowanym lub znacznym, kształcenia ogólnego dla branżowej szkoły I stopnia, kształcenia ogólnego dla szkoły specjalnej przysposabiającej do pracy oraz kształcenia ogólnego dla szkoły policealnej, Dz. U. z 24 lutego 2017 r., poz. 356). 